\title{
Comunidade segundo o Espírito: fraternidade e libertação. Uma aproximação pneumatológica entre Francisco de Assis e José Combin
}

Orientador: Luiz Fernando Ribeiro Santana

Doutorando: Carlos Roberto de Oliveira Charles

Área de Concentração: Teologia Sistemático-Pastoral

Linha de Pesquisa: Fé e Cultura

A compreensão sobre a comunidade de fé segundo Espírito pode ser facilitada por duas balizas que se equilibram e se completam numa mesma ação: fraternidade e libertação. Embora focalizadas e priorizadas separadamente sustentam, por obra do Espírito a mesma vivência da fé na comunhão que exprime amor e liberdade, manifestando-se de muitos modos. Uma destas manifestações é experimentada na fraternidade que gera amor e comunhão entre os membros de uma mesma comunidade e de outras, suscitadas pelo Espírito. Outras manifestações acenam para a transformação integral do ser humano, cuja ação se dá também na expressão evangélica de vida comunitária como processo de libertação. Pensar uma pneumatologia que traga novos sopros de vida para a Igreja é fazer teologia. Por esta razão, o presente trabalho acadêmico, ao articular a espiritualidade experimentada "por" e "em" torno de Francisco de Assis com o pensamento combliniano, pretende demonstrar que esta manifestação do Espírito Santo, diversa no tempo e no espaço e convergente na vida comunitária de fé, concretiza-se como ação fraterno-libertadora de modo muito especial na comunidade por ele suscitada, conduzida e renovada. Para Francisco de Assis essa "comunidade segundo o Espírito" baseia-se no amor e em sua expressão mais fundamental, a "fraternidade". Já na perspectiva teológica de J. Comblin abre possibilidades de reflexão para esta manifestação "libertadora" do Espírito Santo, iluminando uma prática eclesial comprometida com o amor e a justiça, configuração de uma nova espiritualidade marcada pela vida solidária, pela fé partilhada e pela esperança consolidada.

Palavras-chave: Espírito Santo. Libertação. Liberdade. 